\title{
Odpowiedzialność kierownika budowy za bezpieczeństwo na budowie
}

\author{
Michal Czopek \\ Politechnika Częstochowska, e-mail:dexxaa@gmail.com
}

\begin{abstract}
Streszczenie: W artykule przedstawiono problem wypadkowości w dziedzinie budownictwie w oparciu o dane statystyczne. Omówiono funkcję kierownika budowy oraz przepisy prawne (Prawo budowlane, Kodeks pracy, Kodeks cywilny), które określają zakres jego obowiązków oraz odpowiedzialność w przypadku zaniedbań mogących doprowadzić do utraty zdrowia lub życia ludzi. Opisano przykład zaistniałego wypadku, a także kary dla kierownika budowy z tytułu odpowiedzialności zawodowej. W podsumowaniu przedstawiono rolę dziennika budowy, jako dokumentu dowodowego w postępowaniu dyscyplinarnym prowadzonym przeciwko kierownikowi budowy. Przedstawiono również przykład dobrych praktyk, które dotyczyły analizowania sytuacji związanych z zaistnieniem danego wypadku.
\end{abstract}

Słowa kluczowe: kierownik budowy, obowiązki, wypadek, odpowiedzialność.

\section{Wprowadzenie}

Budownictwo to dziedzina gospodarki o stosunkowo dużym ryzyku występowania wypadków przy pracy. Zapewnienie bezpieczeństwa pracy spoczywa na pracodawcy. Obowiązek ten wynika z zapisów najwyższego aktu prawnego jakim jest Konstytucji Rzeczypospolitej Polskiej. Zapis art. 66 konstytucji stanowi - „Każdy ma prawo do bezpiecznych i higienicznych warunków pracy. Sposób realizacji tego prawa oraz obowiązki pracodawcy określa ustawa". Ustawą określającą obowiązki spełnienia konstytucyjnych zapisów jest ustawa z dnia 26 czerwca 1974 r. Kodeks pracy (tj. Dz.U. z 2014 r. poz. 1502 z póź. zm.) [2]. Obowiązki pracodawcy zapewnienia pracownikom bezpiecznych i higienicznych warunków pracy oraz stosownych szkoleń wynikają z zapisów art.15 - jako podstawowa zasada prawa pracy i art. 94. Bardzo istotnymi są również zapisy działu dziesiątego „Bezpieczeństwo i higiena pracy", gdzie w art. 207 czytamy, iż pracodawca ponosi odpowiedzialność za stan bezpieczeństwa i higieny pracy $\mathrm{w}$ zakładzie pracy oraz, że pracodawca jest obowiązany chronić zdrowie i życie pracowników, przez zapewnienie bezpiecznych i higienicznych warunków pracy, przy odpowiednim wykorzystaniu osiągnięć nauki i techniki.

Problem wypadkowości w budownictwie to duży problem. Pomimo tendencji spadkowych liczba wypadków w dalszym ciągu jest duża. Rok 2015 niechlubnie się zapisał w statystyce: statystyki - liczba wypadków śmiertelnych była większa o 14 osób w odniesieniu do roku poprzedniego. Poniższy wykres (Rys. 1) przedstawia liczbę wypadków ciężkich i śmiertelnych w resorcie budownictwa w latach $2010-2015$ [3][4][5].

Celem porównania wypadkowości w budownictwie z innymi resortami gospodarki przedstawiono wykres pięciu resortów o największej liczbie wypadków śmiertelnych zaistniałych w 2015 r (Rys. 2).

Rozpatrując kwestię wypadków w danym resorcie należy problem ten rozważyć $\mathrm{w}$ aspekcie liczby zatrudnionych. W takim zestawieniu budownictwo zajmuje niechlubne pierwsze miejsce. 


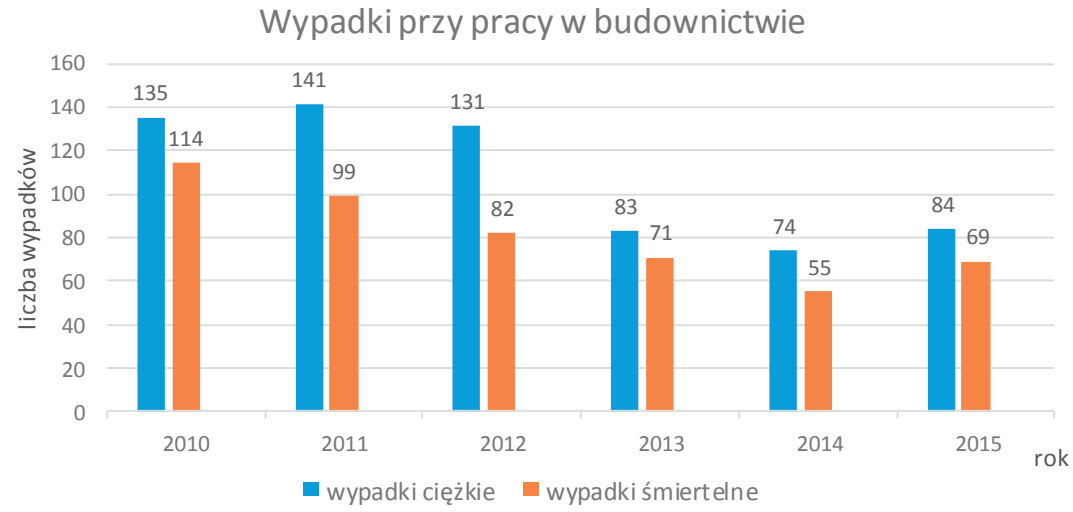

Rys. 1. Wypadki śmiertelne i ciężkie w budownictwie

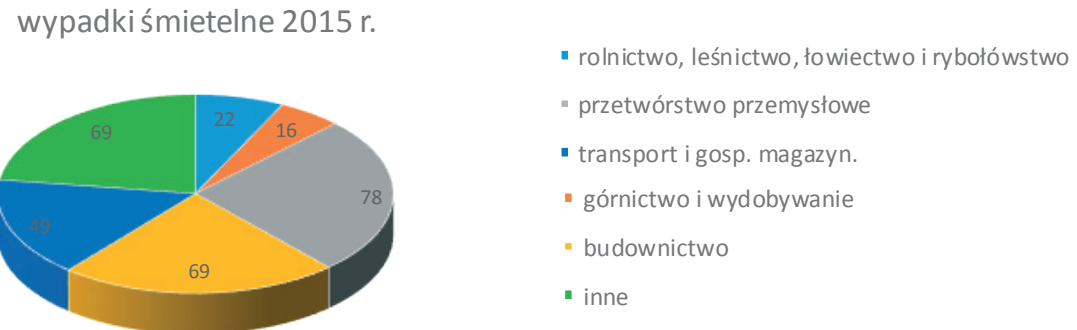

Rys. 2. Wypadki śmiertelne w wybranych dziedzinach gospodarki

\section{Funkcja kierownika budowy}

Kierownik budowy jest to osoba posiadająca uprawnienia budowlane w stosownej specjalności, która podjęła się w procesie budowlanym samodzielnej funkcji technicznej. Składa on do organu nadzoru budowlanego stosowne oświadczenie wraz z kopią właściwych uprawnień budowlanych oraz zaświadczenie o przynależności do izby zawodowej. Kierownik budowy w przypadku, gdy stwierdzi możliwość powstania zagrożenia ma obowiązek wstrzymania robót budowlanych oraz obowiązek bezzwłocznego powiadomienia o tym fakcie właściwego dla miejsca budowy powiatowy inspektorat nadzoru budowlanego. Stwierdzenie ,powstanie zagrożenia” można interpretować, jako każdego rodzaju zagrożenie związanego z budową, a więc w szczególności zagrożenia zdrowia i życia ludzi, zagrożenie mienia, zagrożenie środowiska czy też zagrożenie dla realizowanego obiektu. Wykonując samodzielną funkcję, kierownik budowy nie powinien liczyć na jakikolwiek współudział innych podmiotów procesu budowlanego, w razie zaistnienia niekorzystnych zdarzeń w realizowanym zakresie bezpieczeństwa robót. Należy podkreślić, że każda osoba wykonująca samodzielną funkcję techniczną (w myśl Prawa budowlanego) składając przysięgę deklaruje gotowość wykonywania zawodu zaufania publicznego związanego z realizacją zadań istotnych dla ogółu społeczeństwa. Kierownik budowy wykonując swój zawód spełnienia oczekiwania społecznego beneficjenta, który ocenia tworzone w procesie budowlanym dobro publiczne. Nie powinien zatem, postrzegać wyłącznie korzyści ekonomicznych swojego pracodawcy. Naganna jest zgoda kierownika budowy na poszukiwanie oszczędności finansowych poprzez unikanie ponoszenia niezbędnych nakładów finansowych, na zapewnienie właściwego bezpieczeństwa. Kierownik budowy winien dbać 
o poprawny przebieg realizacji procesu budowlanego. Spełnienie tego obowiązku staje się ograniczonym w przypadku gdy, wyraża on zgodę na realizację innych nie wynikających z przepisów Prawa budowlanego a polecanych przez pracodawcę czynności, takich jak prowadzenie rozliczeń finansowych budowy, sporządzanie ofert przetargowych, itp. czynności nie związanych bezpośrednio z realizacją robót na budowie. Również ograniczone jest poprawne pełnienie obowiązków kierownika budowy, w przypadku wyrażenia zgody, na podejmowanie tej funkcji na znacznie odległych od siebie budowach

\section{Odpowiedzialność w myśl przepisów Kodeksu pracy}

Odpowiedzialność za stan bezpieczeństwa i higieny pracy w zakładzie pracy ponosi pracodawca. W myśl art.120 Kodeksu pracy: „W razie wyrządzenia przez pracownika, przy wykonywaniu przez niego obowiązków pracowniczych, szkody osobie trzeciej, zobowiązany do naprawienia szkody jest wyłącznie pracodawca". Oznacza to, że tylko pracodawca jest odpowiedzialny za ten stan, a nie żadna inna osoba. Rozpatrując tę kwestię na gruncie prawa za wykroczenia popełnione przeciwko prawom pracownika, odpowiedzialnością za popełnione przestępstwa (odpowiedzialność karna) oraz odpowiedzialnością cywilną za wyrządzone szkody na osobie lub w mieniu należy wskazać na zapisy art. 283 „Kto, będąc odpowiedzialnym za stan bezpieczeństwa i higieny pracy albo kierując pracownikami lub innymi osobami fizycznymi, nie przestrzega przepisów lub zasad bezpieczeństwa i higieny pracy, podlega karze grzywny od $1000 \mathrm{zł}$ do $30000 \mathrm{zł.”} \mathrm{W} \mathrm{aspekcie} \mathrm{powyższego} \mathrm{zapisu}$ winniśmy odpowiedzieć na pytanie, jakie przepisy prawne nakładają odpowiedzialność zapewnienia bezpieczeństwa pracy na kierownika budowy. Stosownym dokumentem określającym obowiązki kierownika budowy jest ustawa z dnia 7 lipca 1994 r. Prawo budowlane.

\section{Odpowiedzialność w myśl przepisów Prawa budowlanego}

Odpowiedzialność kierownika budowy reguluje ustawa z dnia 7 lipca 1994 r. Prawo budowlane (Dz.U. z 2016 r., poz. 290) [6]. Zgodnie z jego zapisami w art. 22 na kierownika budowy nałożono obowiązki, do których należy między innymi:

- kierowanie budową obiektu budowlanego w sposób zgodny z przepisami bezpieczeństwa i higieny pracy,

- koordynowanie realizacji zadań zapobiegających zagrożeniom bezpieczeństwa i ochrony zdrowia,

- koordynowanie działań zapewniając przestrzeganie podczas wykonywania robót budowlanych zasad bezpieczeństwa i ochrony zdrowia zawartych w przepisach dotyczących bezpieczeństwa i higieny pracy oraz w planie bezpieczeństwa i ochrony zdrowia.

W myśl art. 23 wyżej wymienionej ustawy kierownik budowy ma prawo występowania do inwestora o zmiany $\mathrm{w}$ rozwiązaniach projektowych, jeżeli są one uzasadnione koniecznością zwiększenia bezpieczeństwa realizacji robót budowlanych. Przepisy Prawa budowlanego w art. 95 i 96 określają odpowiedzialność zawodową w budownictwie oraz zakres kar z tytułu czynów powodujących tę odpowiedzialność.

Odpowiedzialność zawodową kierownika budowy z tytułu niedopełnienia warunków BHP określa art. 95, który brzmi: „Odpowiedzialności zawodowej w budownictwie podlegają osoby wykonujące samodzielne funkcje techniczne w budownictwie, które:", w szczególności punkt 3 , wskutek rażących błędów lub zaniedbań, spowodowały zagrożenie życia lub zdrowia ludzi, ...”. 
W przypadku zaistnienia takiej okoliczności zastosowanie maja przepisy: „Art. 96.1. Popełnienie czynów powodujących odpowiedzialność zawodową w budownictwie jest zagrożone następującymi karami:

1. upomnieniem;

2. upomnieniem z jednoczesnym nałożeniem obowiązku złożenia, w wyznaczonym terminie, egzaminu, o którym mowa w art. 12 ust. 3; (tj. egzaminu na uprawnienia budowlane),

3. zakazem wykonywania samodzielnej funkcji technicznej $\mathrm{w}$ budownictwie, na okres od roku do 5 lat, połączonym z obowiązkiem złożenia, w wyznaczonym terminie, egzaminu, o którym mowa w art. 12 ust. 3."

\section{Odpowiedzialność w myśl przepisów Kodeksu karnego}

Przepisy odnoszące się do odpowiedzialności karnej są ujęte w akcie prawnym, którym jest Ustawa z dnia 6 czerwca 1997 r. Kodeks karny (Dz.U. z 1997 r. poz.553 z póź. zm.), a penalizacją objęte są czyny zabronione karą, jako przestępstwa lub wykroczenia. W przepisach Kodeksu karnego (art.148 - 162) wymieniono przestępstwa przeciwko życiu i zdrowiu, przy czym art.155-157 kolejno stanowią:

Art. 155

Kto nieumyślnie powoduje śmierć człowieka, podlega karze pozbawienia wolności od 3 miesięcy do lat 5 .

Art. 156.

$\S 1$. Kto powoduje ciężki uszczerbek na zdrowiu w postaci:

1. pozbawienia człowieka wzroku, słuchu,

2. innego ciężkiego kalectwa, ciężkiej choroby nieuleczalnej lub długotrwałej, choroby realnie zagrażającej życiu, trwałej choroby psychicznej, całkowitej albo znacznej trwałej niezdolności do pracy w zawodzie lub trwałego, istotnego zeszpecenia lub zniekształcenia ciała, podlega karze pozbawienia wolności od roku do lat 10.

$\S 2$. Jeżeli sprawca działał nieumyślnie, podlega karze pozbawienia wolności do lat 3.

$\S 3$. Jeżeli następstwem czynu określonego w $§ 1$ jest śmierć człowieka, sprawca podlega karze pozbawienia wolności od lat 2 do 12.

Art. 157.

$\S 1$.Kto powoduje naruszenie czynności narządu ciała lub rozstrój zdrowia, inny niż określony w art.156 § 1. podlega karze pozbawienia wolności od 3 miesięcy do lat 5.

$\S 2$ 2.Kto powoduje naruszenie czynności narządu ciała lub rozstrój zdrowia trwający dłużej niż 7 dni, podlega grzywnie, karze ograniczenia wolności albo pozbawienia wolności do lat 2.

$\S$ 3. Jeżeli sprawca czynu określonego w $\S 1$. lub 2. działał nieumyślnie, podlega grzywnie, karze ograniczenia wolności, albo pozbawienia wolności do roku.

$\S 4$. Ściganie przestępstwa określonego w $§ 2$. lub 3., jeżeli naruszenie czynności narządu ciała lub rozstrój zdrowia nie trwał dłużej niż 7 dni, odbywa się z oskarżenia prywatnego, chyba że pokrzywdzony jest osoba najbliższa wspólnie zamieszkująca ze sprawcą.

$\S 5$. Jeżeli naruszenie czynności narządu ciała lub rozstrój zdrowia trwał dłużej niż 7 dni, a pokrzywdzonym jest osoba najbliższa, ściganie przestępstwa określonego w $\S 3$. następuje na jej wniosek. [7]

Naruszenie powyższych przepisów poczytywane jest jako zaistniałe w wyniku zaniechania lub błędu. W przypadku kierownika budowy sytuacje te są w szczególności niezamierzonym skutkiem, polegającym na niezachowaniu obowiązku oceny zagrożenia, dbało- 
ści o bezpieczeństwo i życie ludzkie, przewidywania konsekwencji własnego zachowania, które ostatecznie doprowadziło do zaistniałego następstwa.

\section{Plan bezpieczeństwa i ochrony zdrowia, zwanym BIOZ}

Plan bezpieczeństwa i ochrony zdrowia zwanym BIOZ jest to dokument, którego obowiązek sporządzenia lub zapewnienia sporządzenia należy do kierownika budowy. Kierownik budowy może powierzyć sporządzenie tego dokumentu innej osobie lub firmie posiadającej stosowne kompetencje. Plan BIOZ określa założenia bezpiecznej pracy przy uwzględnieniu specyfiki obiektu budowlanego i warunków prowadzenia robót budowlanych, jak również planowanego jednoczesnego prowadzenie robót budowlanych i produkcji przemysłowej. Obowiązek sporządzenia planu BIOZ istnieje, jeżeli w trakcie budowy wykonywany będzie przynajmniej jeden z rodzajów robót budowlanych, których charakter, organizacja lub miejsce prowadzenia stwarza szczególnie wysokie ryzyko powstania zagrożenia bezpieczeństwa i zdrowia ludzi, a w szczególności przysypania ziemią lub upadku z wysokości i innych, wymienionych w odnośnych przepisach lub gdy przewidywane roboty budowlane mają trwać dłużej niż 30 dni roboczych i jednocześnie będzie przy nich zatrudnionych co najmniej 20 pracowników lub pracochłonność planowanych robót będzie przekraczać 500 osobodni. Szczegółowy zakres i formę informacji bezpieczeństwa i ochrony zdrowia oraz planu bezpieczeństwa i ochrony zdrowia przy uwzględnieniu specyfiki projektowanego obiektu określa Rozporządzenie Ministra Infrastruktury z dnia 23 czerwca 2003 r. w sprawie informacji dotyczącej bezpieczeństwa i ochrony zdrowia (Dz.U. z 2003 r. poz.1126). Informację bezpieczeństwa i ochrony zdrowia sporządza projektant, a plan bezpieczeństwa i ochrony zdrowia sporządza, jak już to wskazano powyżej, kierownik budowy.

\section{Odpowiedzialność przed Okręgową Izbą Inżynierów Budownictwa}

Prawo budowlane $(\mathrm{Pb})$ określa nie tylko obowiązki i prawa kierownika budowy lecz również ustanawia przepisy karne oraz odpowiedzialność zawodową $\mathrm{w}$ budownictwie. Zgodnie z zapisem art.50 ust.1 pkt $2 \mathrm{w}$ przypadkach prowadzenia robót budowlanych , w sposób mogących spowodować zagrożenie bezpieczeństwa ludzi lub mienia bądź zagrożenie środowiska" właściwy organ wstrzymuje postanowieniem prowadzenie robót, a zgodnie z art. 90 osoba, która wykonuje te roboty budowlane, tj. kierownik budowy podlega grzywnie, karze ograniczenia wolności albo pozbawienia wolności do lat 2. W myśl art. 95 pkt $3 \mathrm{~Pb}$ odpowiedzialności zawodowej w budownictwie podlegają osoby wykonujące samodzielne funkcje techniczne w budownictwie, które - między innymi wskutek rażących błędów lub zaniedbań, spowodowały zagrożenie życia lub zdrowia ludzi, bezpieczeństwa mienia lub środowiska albo znaczne szkody materialne. Przepis ten dotyczy - w głównej mierze - kierownika budowy.

Postępowanie w sprawie odpowiedzialności zawodowej w budownictwie jest prowadzone na wniosek właściwego organu nadzoru budowlanego lub samorządu zawodowego, tj. okręgowej izby inżynierów budownictwa. Orzeczenia dokonywane są przez organy samorządu zawodowego (okręgowy sąd dyscyplinarny i okręgowego rzecznika odpowiedzialności zawodowej). Ostateczna decyzja o ukaraniu jest przesyłana do wiadomości: jednostce organizacyjnej zatrudniającej ukaraną osobę, właściwemu stowarzyszeniu, organowi który wydał uprawnienia ukaranemu uprawnienia do pełnienia samodzielnej 
funkcji technicznej w budownictwie, Głównemu Inspektorowi Nadzoru Budowlanego. Informacja o karze z tytułu odpowiedzialności zawodowej, orzeczonej ostateczną decyzją, podlega wpisowi do centralnego rejestru ukaranych.

\section{Wypadek przy pracy, wypadek śmiertelny, ciężki wypadek}

Ustawa z 30 października 2002 r. o ubezpieczeniu społecznym z tytułu wypadków przy pracy i chorób zawodowych (Dz.U. z 2009 r. poz.1322) klasyfikuje wypadki jak niżej:

- za wypadek przy pracy uważa się nagłe zdarzenie, wywołane przyczyną zewnętrzną, powodujące uraz lub śmierć, które nastąpiło w związku z pracą:

1. podczas lub w związku z wykonywaniem przez pracownika zwykłych czynności lub poleceń przełożonych;

2. podczas lub w związku z wykonywaniem przez pracownika czynności na rzecz pracodawcy, nawet bez polecenia;

3. w czasie pozostawania pracownika $\mathrm{w}$ dyspozycji pracodawcy,

4. między siedzibą pracodawcy a miejscem wykonywania obowiązku wynikającego ze stosunku pracy.

Określone zdarzenie może być zakwalifikowane jako wypadek przy pracy jedynie wówczas, gdy spełnia równocześnie wszystkie cztery warunki podane w definicji. Jako wypadek śmiertelny przy pracy uważa się wypadek, w wyniku którego nastąpiła śmierć poszkodowanego pracownika w okresie 6 miesięcy od zdarzenia. Za ciężki wypadek przy pracy uważa się wypadek, w wyniku którego nastąpiło ciężkie uszkodzenie, takie jak: utrata wzroku, słuchu, mowy, zdolności rozrodczej lub inne uszkodzenie ciała albo rozstrój zdrowia naruszające podstawowe funkcje organizmu, a także choroba nieuleczalna lub zagrażająca życiu, trwała choroba psychiczna, całkowita lub częściowa niezdolność do pracy w zawodzie albo trwałe, istotne zeszpecenie lub zniekształcenie ciała [9].

\section{Wyrok w imieniu Rzeczypospolitej Polskiej}

Zgodnie z podstawową zasadą zapisaną w Kodeksie cywilnym każdy, kto ze swojej winy wyrządzi innemu szkodę jest obowiązany do jej naprawienia. Za szkodę odpowiada osoba, której zawinione działanie jak również zaniechanie wykonania obowiązku jest przyczyną powstałej szkody. Tym przepisom podlega również kierownik budowy. Poniższy przykład zaistniałego wypadku - wyrok sądu o odszkodowanie, sprawa cywilna o odszkodowanie $\mathrm{z}$ tytułu śmierci pracownika przybliży kwestię odpowiedzialności kierownika budowy w myśl Kodeksu cywilnego.

Wypadek śmiertelny na budowie, rok 2010. [10].

Opis zdarzenia.

Firma budowlana wykonywała roboty dekarskie na budynku (...) przy ul. (...). Do robót dekarskich został skierowany pracownik (...), który w dniu 3.08.2010 roku, schodząc z miejsca pracy, wpadł do niezabezpieczonego otworu w stropie dobudówki, przykrytego folią, i wskutek urazów, doznanych w wyniku tego wypadku, w dniu 5.08.2010 roku zmarł. Przyczyną śmiertelnego wypadku był brak zabezpieczenia drogi poruszania się pracowników, wykonujących prace na wysokości, przed możliwością wpadnięcia do otworu W stropie przykrytego folią. Kierownik budowy - jako pozwany w trakcie przesłuchań oświadczył, że na budowie nie przebywał cały czas. W zakresie swoich obowiązków miał obsługę kilku budów, a na przedmiotowej budowie jego pobyt ograniczał się do kontroli na początki i końcu dnia, według poleceń swojego pracodawcy. W dniu wypadku, zaraz po 
upadku pracownika (...) stwierdził, że do miejsca pracy dekarzy prowadziła bezpieczna droga, rusztowaniem wynajętym od firmy (...). Za zorganizowanie miejsca pracy dekarzy odpowiadał, jego zdaniem, podwykonawca (firma, która realizowała roboty dekarskie). Jako członek okręgowej izby inżynierów budownictwa posiadał obowiązkowe ubezpieczenie od odpowiedzialności cywilnej, na podstawie umowy ubezpieczenia, zawartej pomiędzy Polską Izbą Inżynierów Budownictwa a firmą ubezpieczeniową. Pracodawca nie zawarł pisemnej umowy o pracę z pracownikiem (...) gdyż ten nie posiadał lekarskich badań, określających brak przeciwskazań do pracy na wysokościach. Umowę pisemną przygotowano na czas określony, lecz jej podpisanie odłożono do czasu przeprowadzenia stosownych badań lekarskich. Pracownik (...) odbył w ramach szkolenia wstępnego w dziedzinie bhp instruktaż ogólny oraz instruktaż wolnostanowiskowy, na stanowisku pracownika ogólnobudowlanego. Pracował, podawał materiały z rusztowania. Nie posiadał żadnego zabezpieczenia do pracy na wysokościach w postaci szelek i kasku, gdyż nie zostało mu wydane. Później wszedł po położonych na pochyłej części dachu deskach pomostowych i w górnej częścią „łatach” na płaską cześć dachu, skąd dalej podawał materiały, pracującym na górnej części dachu pracownikom. Około godz. 16.10. jeden ze współpracujących pracowników polecił mu zejście na dół w związku z opadami deszczu i zakończeniem pracy. Pracownik (...) w momencie schodzenia po łatach dachu, wpadł w folie między łatami i spadł z wysokości około $6 \mathrm{~m}$ na betonowe schody, i podest klatki schodowej. Po upadku nieprzytomny został odwieziony do szpitala, gdzie w dniu 5.08.2009 roku, wskutek odniesionych obrażeń po upadku z wysokości, zmarł.

Według kontroli przeprowadzonej przez Państwową Inspekcję Pracy przyczynami wypadku były:

- brak wyznaczenia drogi komunikacyjnej, prowadzącej z rusztowania elewacji na płaską część dachu nad spocznikiem schodów,

- brak możliwości korzystania ze środków ochrony indywidualnej, zabezpieczających przed upadkiem z wysokości,

- brak balustrady przy pomoście zabezpieczającej pracowników podczas przechodzenia po deskach pomostowych na pochyłą części dachu,

- brak dostatecznego nadzoru nad pracami szczególnie niebezpiecznymi, tj. pracami dekarskimi na wysokości,

- wykonywanie pracy przez poszkodowanego bez wymaganych badań lekarskich.

- Kontrola wykazała również, że na terenie wykonywanych prac dekarskich nikt $\mathrm{z}$ zatrudnionych w kontrolowanym podmiocie nie sprawował funkcji brygadzisty, bądź też innej funkcji związanej z nadzorowaniem. Ponadto na wysokości zamontowanego rusztowania nie było balustrad do, których można było przypiąć szelki ochronne.

Kierownik budowy oraz pełnomocnik przedsiębiorstwa realizującego roboty dekarskie, w którym miał być zatrudniony zmarły pracownik, jedynie okresowo przyjeżdżali na teren budowy, w celu zweryfikowania postępu prac oraz sposobu wykonywania prac dekarskich.

Zdaniem Sądu za śmierć pracownika winę ponosi właścicielka przedsiębiorstwa, która nie została skazana wyrokiem karnym. Nie wyklucza to możliwości dochodzenia roszczeń o naprawienie szkody z tytułu czynu niedozwolonego - art.415 Kc w związku z art. $300 \mathrm{Kp} \mathrm{w}$ stosunku do pracodawcy. Na kierowniku budowy, w świetle przepisów ustawy Prawo budowlane, spoczywał obowiązek zorganizowania budowy i kierowanie nią w sposób zgodny z projektem i pozwoleniem na budowę, przepisami, w tym technicznobudowlanymi, oraz przepisami bezpieczeństwa i higieny pracy - art.22.pkt 3. Obowiązkiem kierownika budowy jest przede wszystkim bezwzględne dbanie o to bezpieczeństwo, 
a więc do niego należy skontrolowanie, czy robotnicy zostali wyposażeni przez pracodawcę w środki ochrony osobistej, takie jak: kaski, odpowiednie obuwie, rękawice czy szelki. Kierownik budowy ma obowiązek sprawdzić zaświadczenia lekarskie pracowników dopuszczające ich do pracy na wysokości oraz skontrolować, czy mechaniczny sprzęt budowlany spełnia wymagania w zakresie dopuszczenia do użytkowania, np. świadectwo UDT. Kierownik budowy ma także obowiązek przeprowadzić szkolenie stanowiskowe i odnotować ten fakt w dokumentacji budowy. Jakiekolwiek nieprawidłowości stwierdzone w tym zakresie powinny dyskwalifikować pracownika lub sprzęt od dalszej pracy. Ww. obowiązki kierownik budowy zaniedbał. W wyroku z dnia 22.12.2012 roku kierownika budowy uznano winnym tego, że w dniu 3.08.2010 roku, będąc odpowiedzialny za bezpieczeństwo i higienę pracy z tytułu pełnionej funkcji, nie dopełnił wynikających stąd obowiązków, czym naraził pracowników na bezpośrednie niebezpieczeństwo utraty życia lub ciężkiego uszczerbku na zdrowiu i nieumyślnie spowodował śmierć pracownika. Wyrok ten wiąże Sąd na zasadzie art. $11 \mathrm{Kpc}$. Sąd orzekł, że za wypadek ponosi również winę sam zmarły pracownik. Nie posiadając odpowiednich badań lekarskich, doświadczenia w tego rodzaju pracy oraz stosownego przeszkolenia w zakresie pracy na wysokościach, nie odmówił wykonania czynności. Sąd Rejonowy w postępowaniu karnym przeciwko oskarżonemu kierownikowi budowy warunkowo umorzył na okres próby wynoszący 2 lata.

\section{Wnioski}

Kierownik budowy jest uczestnikiem procesu budowlanego, winien więc czuwać nad prawidłowością jego przebiegu. Do kierownika budowy należą wszystkie sprawy z zakresu bezpieczeństwa wykonywania robót budowlanych, organizacji procesu budowlanego, zabezpieczenia terenu budowy, prowadzenia dokumentacji budowy, przygotowywania odbiorów itd. Wszystkie istotne zdarzenia, jak również związane z BHP winny być odnotowane w dzienniku budowy. Z postępowań dyscyplinarnych prowadzonych przez rzeczników i sądy dyscyplinarne okręgowych izb inżynierów budownictwa wynika, że najczęściej zaniedbywaną czynnością kierowników budów jest bieżące prowadzenie dziennika budowy. W razie popełnienia przez kierownika budowy przewinienia, które staje się przedmiotem postępowania dyscyplinarnego, dziennik budowy jest istotnym dokumentem dowodowym.

Kierownik budowy jest zawsze jeden. Na budowie może występować wielu kierowników robót budowlanych, ale ich funkcje są zawsze służebne wobec kierownika budowy. Udział kierowników robót $\mathrm{w}$ procesie budowlanym nie ogranicza zakresu obowiązków kierownika budowy. Ich odpowiedzialność dyscyplinarna jest analogiczna do odpowiedzialności kierownika budowy. W przypadku zaistnienia na budowie nieszczęśliwego wypadku, wypadku śmiertelnego lub katastrofy budowlanej kierownik budowy jest zobowiązany zorganizować pomoc poszkodowanym, a w dalszej kolejności zabezpieczyć miejsce zdarzenia oraz powiadomić właściwego dla miejsca budowy powiatowego inspektora nadzoru budowlanego, jak również prokuratora, policję, inwestora, Inspektora ds. BHP wykonującego zadania służby BHP w firmie i inne zainteresowane zaistniałą sytuacją jednostki.

Nieszczęśliwy wypadek na budowie, zwłaszcza śmiertelny, to trudne przeżycie dla wszystkich zaangażowanych osób, tak poszkodowanego, jego rodziny, jak również odpowiedzialnego kierownika budowy, zespołu współpracowników i dla firmy wykonawczej. Wypadek na budowie nie powinien być traktowany jako przypadek losowy, na który nie mieliśmy wpływu. Zaistniała sytuacja, jaka doprowadziła do wypadku, winna być przeanalizowana, w celu zmian w standardach BHP, aby w podobnych przypadkach już nikt nie odniósł uszczerbku na zdrowiu lub nie stracił życia. Takie zachowania są praktykowane, niestety, tylko w niektórych firmach. W pewnej firmie (...) bardzo dużą uwagę zwraca się 
na bezpieczeństwo pracy - zachowane są wszelkie, obowiązujące w tej kwestii, standardy. W przypadku, gdy na jednym z placów budów tej firmy Skanska na świecie dochodzi do wypadku śmiertelnego, powstaje tzw. Global Safety Stand Down. Z każdym takim wypadkiem ma być zapoznany każdy pracownik firmy, niezależnie od tego, gdzie pracuje. We wszystkich jednostkach i oddziałach, na zebraniach pracowników jest omawiane zdarzenie, i co zrobiła firma, żeby taka sytuacja się nie powtórzyła. Na koniec takiego spotkania pracownicy minutą ciszy oddają cześć pamięci poszkodowanego [11]. Zasadnym w tej kwestii, wydaje się być również prowadzenie edukacyjnej działalności przez okręgowe izby inżynierów budownictwa. Wskazanym jest publikowanie w prasie izbowej i na swoich stronach internetowych decyzji sądów dyscyplinarnych o ukaraniu osób pełniących samodzielne funkcje techniczne w budownictwie. Informacje takie stanowiłyby przestrogę dla kierownika budowy przed podejmowaniem nadmiernej ilości obowiązków, co powoduje brak możliwości pełnej kontroli budowy.

\title{
Literatura
}

1. http://sip.legalis.pl/document-full.seam?documentId=mfrxilrsgq4tgmjoozsxelrrgq2tgoa

2. http://stat.gov.pl/cps/rde/xbcr/gus/pw_wypadki_przy_pracy_I_IV_2011r.pdf

3. http://stat.gov.pl/obszary-tematyczne/rynek-pracy/warunki-pracy-wypadki-przypracy/wypadki-przy-pracy-w-2013-r-,4,6.html

4. http://stat.gov.pl/obszary-tematyczne/rynek-pracy/warunki-pracy-wypadki-przy-pracy/

5. http://sip.legalis.pl/document-full.seam?documentId=mfrxilrsguydonboozsxelrrgy4tqna

6. http://sip.legalis.pl/document-full.seam?documentId=mfrxilrsguydonroozsxelrrg4ydeoi

7. http://sip.legalis.pl/document-full.seam?documentId=mfrxilruguytembqhe3c45tfoixdcmrtge $2 \mathrm{q}$

8. http://sip.legalis.pl/document-full.seam?documentId=mfrxnbzgeytkltwmvzc4mjwhaydc

9. http://orzeczenia.nowysacz.so.gov.pl/content/\$N/152015000000503_I_C_000794_2013_Uz_2 014-06-30_001

10. http://www.muratorplus.pl/technika/bhp/bhp-case-study-wypadkow-na-budowie-okolicznosciprzyczyny-wypadkow-koszty-dla-firmy_81482.html

\section{The responsibility of the construction manager for the construction site safety}

\author{
Michał Czopek \\ Częstochowa University of Technology,e-mail:dexxaa@gmail.com
}

Summary: In this article the author have presented Polish construction accident statistics, described a construction manager function and the Polish regulations (Building code, Labour code, Civil Code) which determine the manager's responsibilities in the case of negligence that could have a negative effect on people's health and lives. The example of accident and penalties for a construction manager in respect of professional liability were shown. In conclusion the role of building diary as documentary evidence in the disciplinary proceedings against the construction manager was described. There was also presented the examples of good practice in the accident occurrence situations analysis.

Keywords: construction manager, duties, accidents, responsibility. 
